travasated red blood corpuscles. Many of the smaller blood vessels are similarly surrounded by small foci of extravasated blood. In many of these the vessels cannot be made out, suggesting softening. At the peripheries of all these areas of hemorrhage are found moderate numbers of neutrophilic polymorphonuclear leukocytes. No organisms are seen. Gralen's Veins-Section through both shows completely obliterating thrombi. No organisms seen. PonsAll the larger blood vessels in the peduncles are surrounded by areas of extravasated blood. There are no obvious thrombi. Some of medium sized blood vessels appear to have walls of un. usual thickness. Cerebellum-Negative. Spinal Cord-Massive hemorrhage in the meninges.

\section{A TRIBUTE TO A PIONEER IN MODERN PATHOLOGY.}

By J. C. Warken, M.D., Boston, and S. J. MixtTer, M.D., Bostor.

THE death of Dr. William Fiske Whitney on March 4, 1921, was an event which brings home to the memory of his contemporaries a long career of useful service.

Entering on his professional work at a time when the microscope had just begun to be a prominent feature in medical teaching and in the practice of medicine, he was appointed Curator of the Anatomical Museum of the Harvard Medical School in 1879. He brought with him to this office as thorough a training in the laboratory branch of medical education as prevailed at that time in the prominent medical centers of Europe.

$\mathrm{He}$ came into his new position at a transition period when scientific medicine was beginning to assume a prominent place in the medical curriculum. The old anatomical collection, like that of the Musée Dupuytren in Paris, and many others, represented the labors of an earlier generation. The field was an open one for the new-comer, and Dr. Whitney promptly took advantage of the situation and became a pioneer in modern museum work, which, under the fostering influence of the Association of International Museums, has of late years become so prominent a feature of the modern medical plant.

During his long and devoted term of service as Curator, the Museum has twice found it new home, and a comparison of the present quarters with those in the old building on North Grove Street, of which Dr. Holmes said: "Oh, star-eyed Science, hast thou wandered there!" is a sufficient indication of the amount of work Dr. Whitney has been able to accomplish. The character of his work in this field is best enumerated by one who has rendered him faithful and efficient service during many years.*

* Miss E. Harrict Pjper.
"Dr. Whitney was especially fitted to fill the position of Curator, on account of his wide range of knowledge on all subjects, and his familiarity with more than half a dozen different languages.

"He spent much time and thought on the present home of the Collection, visiting many museums in various parts of the country, which enabled him to eliminate impractical features. When the time came for moving the thousands of specimens, the picture of every detail was so clearly in his mind, and they were packed in such a manner that he was able to put them at once in their proper places, and not one specimen was injured.

"He succeeded so well in the accomplishment of his purpose that during the Medical and Surgical Congress in June, 1921, strangers from various countries expressed their admiration of what they considered 'one of the finest museums they had ever had the good fortune to visit.'

"Dr. Whitney aimed to have the museum simple, quiet and dignified, as it represented human suffering, and he hoped in the study of the specimens, alleviation of pain might be found. It was to him a sacred trust, in the fulfilling of which he never spared himself in any way. He felt that the value of the Museum was in its use, and extended the resources as far as it was consistent with the safety of the specimens, and a request was never refused under these conditions. As a result, many valuable contributions were secured because the donor felt 'they would be carefully preserved." "'

But it is in another field that Dr. Whitney will probably be best remembered by his contemporaries. Dr. Whitney was preëminently a clinical pathologist and his intimate association with many medical and surgical colleagues at a time when the field of medical practice was greatly expanding, enabled him to be of great service to them in their practice. The pathological reports which he sent to his medical colleagues at a time when the practising physician was becoming more and more dependent upon pathological findings, were models of their kind.

It was, however, in the domain of surgery that he was able to figure as a pioneer in a special line of work. The surgeon of today has little conception of the difficulty of obtain. ing reports upon examination of tumors and other morbid specimens, which prevailed at that time. The specimen was often lost or rendered unfit for microscopical examination. This was true of hospital as well as of private clinical work. The Cabot endowment for a laboratory for such a purpose at the Massachusetts 
General Hospital, enabled Dr. Whitney to train himself to meet the demands of the time, and this experience was followed up by his active participation in private surgical work. Accompanying the surgeon, as he did, to the place of operation, he soon found the necessity of perfecting a method of rapid diagnosis. At the hospital an appropiate apparatus made it possible for him to obtain frozen sections for this purpose.

But eventually his long experience and tactical skill enabled him to dispense with such adventitious aids, and he could give a reliable opinion on any doubtful point bearing upon the character or scope of the operation which was of invaluable service to the operating surgeon. It is hardly more than fair to say that Dr. Whitney was not only the pioneer, but the originator of this form of quick diagnosis. To many surgeons his presence at such operations was indispensable, and his final written report was of greatest value in enabling the surgeon to forecast the future of a given case.

Dr. Whitney in his long career has undoubtedly left many valuable written contributions to his department of medicine, but it will be by the work he was able to accomplish along. the lines indicated above that he will be most gratefully remembered. So extensive and varied was his experience in the later years of his life that his opinion was regarded as a standard authority.

Dr. Whitney had a large amount of valuable information on many other subjects which would have been more conspicuous, had it not been for the modest estimate of his own qualifications, and his retiring disposition. $\mathrm{He}$ was always to be found either at his laboratory table at the hospital or at his desk in the museum.

On the removal of the Harvard Medical School to its present quarters the Museum was fortunate in receiving a handsome endowment, and the manner in which Dr. Whitney administered its finances enabled him to make, from time to time, many valuable additions, and when the call finally came, it was shown that his trust had been administered with discretion and fidelity.

Covering, as he did, a period of work which extended beyond that of a single generation, he lived to see vast changes in the methods of research and great additions to the knowledge of his special branch of medicine. He grew old in a service in which new ideas and new methods were constantly making their appearance. The vast field thus opened was greater than it was possible for any one man to cover, but the lines along which he made his first beginnings and to which it is probable he wisely confined himself hold good today.

Dr. Whitney was born in Boston March 26,
1850, and died March 4, 1921, of cerebral hemorrhage.

He graduated from Harvard University in 1871, and from Harvard Medical School in 1875. He then studied anatomy, pathology and other subjects in Vienna, Berlin, Munich and Strassburg. Upon returning to this country he was appointed pathologist to the Massachusetts General Hospital in 1878, and the following year, 1879, he was appointed Curator of the Warren Anatomical Museum, Harvard Medical School, and continued in this position for 42 years, until his death.

In 1888 he married Louisa Elliot of Stockton, Calif., who, with two sons, Lyman Fiske Whitney and William Elliot Whitney, survive him. From 1883 to 1890 , Dr. Whitney was Secretary of the Medical Faculty, and part of that time was also Acting Dean. About this time he was sent to Europe by the Government for the investigation of tuberculosis. From 1891 to 1901 he was connected with the Harvard University Veterinary School as Professor of Parasites and Parasitical Diseases. He served on the committee to superintend the building of the old medical school on Boylston Street in 1880 , and twenty years later served in a similar capacity in erecting the new group of buildings on Longwood Avenue. He was also for many years on the Administrative Board of the Medical School, filling that position during the first years in the buildings now occupied by the school.

$\mathrm{He}$ was President of the Obstetrical Society and presided at the fiftieth anniversary. He also had been President of the Massachusetts General Hospital Alumni Association, VicePresident of the Boston Society of Natural History, having been connected with it for many years. He was a member of the American Medical Association, the Massachusetts Medical Society, the International Association of Medical Museums, and many others.

One of his life studies was carcinoma, and he was author of many articles on the subject. In 1901 he gave the Shattuck Lecture at the annual meeting of the Massachusetts Medical Society, on "The Alleged Increase of Cancer in Massachusetts." This was the result of his studies of statistics from all over the world, and from which he made his "Comparative Study of Death Rates from Cancer for the years 1850, 1875 and 1900." For many years he made up his results every five years.

The long friendship with Dr. Whitney, for some of us, had its beginning when he first took up his professional work in the old building of the Medical School in North Grove Street, - that old, cramped, inconvenient building. with its history and traditions, its wonderful teachers, its out-of-date chemical and pathological laboratories, with only two lecture rooms, its steep stairs to the anatomical amphitheatre, and its museum, in small and crowded 
quarters, with its imposing array of phrenological casts, as well as the splendid dissections of Holmes, Hodges, Jackson and other masters.

We saw him bring order out of chaos, introduce what were then modern methods, and, with his exceptional skill with the microscope, added to his executive ability, assist in building up and encouraging the splendid system of pathological and bacteriological teaching of which we are so proud.

Those were the days when scientific instruments and appliances were few, and money to buy them not to be had from the school, when alcohol and other chemicals were hard to get for lack of funds. There were no microtomes worthy of the name, and all the discoveries and advances in microscopical pathology had been made through the study of hand-made razor sections, and a large, thin section was unknown, even to Bilroth. Is it not probable that training in this school of scanty equipment was what helped to give Dr. Whitney his wonderful skill in quick diagnosis, and knack in the examination of fresh specimens?

Then came the construction of and moving into the new building on Boylston Street, the building that seemed, at the time, to be ample for the needs of the school for many years. Moving the precious contents of the old museum to their new quarters that he had so carefully planned was an anxious time, for it meant not only moving without breakage, or other damage, but the elimination of the useless and unfit. This being safely accomplished, it only remained for him to move into the new Sears laboratory in order to gain fresh impetus for his work and for him to grow in knowledge and skill, a growth that ended only with his life.

And that life was a happy one; happy in his family and home, happy in his friendships,for he never had an enemy,-happy in his work.

To that work he devoted himself too closely, his friends thought. Every day at the school, every day at the hospital, and his constantly increasing consultation and medico-legal work left little time for recreation and relaxation. Even during the short summer vacation that he allowed himself, he was always on duty call, though no one loved the call of the sea more than he did, and no one who knew him well ever summoned him from his boat or his rest without regretting the necessity for so doing.

There is no branch of the medical profession which does not owe much to Dr. Whitney, but to the surgeons associated with him he became a necessity, a part of their professional lives. The hesitating surgeon, knife in hand, uncertain whether to do a trifling operation or one terribly mutilating and severe, could always depend on the decision of his master mind and vast experience, and a great number of men and women today owe their intact bodies, or their lives, to his quietly spoken opinion.

In the hospital or in the home, with the rich or the poor, his presence meant the difference between haphazard surgery and intelligent surgery, between life and death. In the domain of rapid, exact surgical diagnosis, he was the unquestioned leader.

Another field in which he excelled, was in medico-legal work. His opinions and conclusions were always convincing, his decisions were accepted by the counsel for both sides, and he was universally commended for his fairness to both plaintiff and defendant. $\mathrm{He}$ never made a statement that he was not perfectly sure of, and could substantiate in every way.

As a medical man, he was able, exact, careful, progressive and just.

As a man, husband, father and friend, he was lovable and loving, kindly, gentle, courteous and too modest; a power for good in the hospital, school and community. In his death mankind has lost a willing helper, and we, a dear and devoted friend.

\section{A Partial list of Articles Published by Dr. Whitney.}

The Identification of Seminal Stains. (1897.)

The Possibilities and Limitations of Microscopic Diagnosis. The Alleged Increase of Cancer in Massachusetts. (1901.)

Classification of Cancer upon an Embryological Basis. (1901.)

Comparative Study of the Death Rates for the State of Massa chusetts for the Years 1850,1875, and 1900. (1904.)

Study of Birth 'Rates, General Death Rates and Delath Rates from Cancer for the New England States for the Year 1900. (1905.)

Study of the Statistics of Cancer in Massachusetts for the Year 1905. (1910.)

Quick and Simple Method fom Fixing the Blood Corpuscles for Differential Staining. (1901.)

Notes on the Production of the Test Serum in Rabbits. (1902.)

Pyronin-Methyl Green.; a Brilliant Double Stain for Cells and Bacteria. (1903.)

A Brain Hardening by Jaiserling Method Showing the Track of a Bullet. (1903.)

The Aloin and Guiac Test for Blood Depends Solely upon the Iron Contained in the Hemoglobin. (1907.)

Varicose Veins of the Papilla of the Kidney. A Cause for Persistent Fematuria. (1908.)

The Gailloux Murder. A Case Solely of Circumstantial Evidence with Conviction of the Murderer. (1909.)

A Delicate Method of Obtaining Hemin Crystals from Minute Blood Stains. (1912.)

Cvanic Poison and the Tests for Its Detection. (1915.)

Observations on Obtaining Hemin Crystals from Dried Blood. (1920.)

Sudden" Death Following Intravenous Injection of Neosalvarsan. (1921.)

\section{THE RESPONSIBILITY FOR DIPHTHERIA}

\section{By Joseph Gartand, M.D., Boston.}

Diphtheria, always a menace and public health problem, has become a public disgrace. While diphtheria was still a disease of unknown etiology, difficult of diagnosis and unsatisfactory to treat, it was feared because of the enormous toll it exacted and because the medical profession was without power in its efforts at control. These times have changed. Diphtheria can now be successfully treated and entirely controlled, and, if the proper measures were always adopted and uniformly carried 